\title{
Planning a Career in Engineering: Parental Effects on Sons and Daughters
}

\author{
Jerry A. Jacobs ${ }^{1, *}$, Seher Ahmad ${ }^{2}$ and Linda J. Sax ${ }^{3}$ \\ 1 Department of Sociology, University of Pennsylvania, 3718 Locust Walk, McNeil Building, Rm. 113, \\ Philadelphia, PA 19104-6299, USA \\ 2 Harvard Strategic Data Partnership Fellow, Delaware Department of Education, The Townsend Building, \\ 401 Federal Street, Suite 2, Dover, DE 19901-3639, USA; seher.ahmad@doe.k12.de.us \\ 3 Graduate School of Education and Information Studies, University of California, Los Angeles, \\ CA 90095-1521, USA; 1sax@ucla.edu \\ * Correspondence: jjacobs@upenn.edu; Tel.: +1-215-898-1536
}

Academic Editors: Maria Charles and Sarah Thébaud

Received: 20 July 2016; Accepted: 23 December 2016; Published: 4 January 2017

\begin{abstract}
This paper examines the extent to which prospective engineers follow in their parents footsteps. Specifically, we investigate the connection between fathers' and mothers' employment in the engineering profession and the career plans of sons and daughters. We develop a number of reasons to expect an occupation-specific intergenerational association in this field, as well as hypotheses regarding gender-specific role-modeling. Data are drawn from the UCLA HERI Freshman Survey data spanning 1971 to 2011. The results point to clear and substantial effects on sons and daughters' plans to pursue engineering, connections that cannot be explained by typical pathways such as social background, education and values. The evidence points to a pattern of increasing salience of mothers with respect to the career plans of their children, especially their daughters. The implications of these findings for the under-representation of women in engineering and for gender-specific family dynamics are discussed in the conclusion.
\end{abstract}

Keywords: gender; STEM fields; career choices; college majors; occupational mobility

\section{Introduction}

Despite a long and rich history of research on occupational mobility and career choice, researchers have rarely explored intergenerational occupational inheritance at the level of specific occupations. In this paper, we add to a small and diverse literature on this topic by investigating the extent to which college freshmen plan to follow their parents into the engineering profession.

The under-representation of women in STEM (Science, Technology, Engineering and Mathematics) fields has long been the focus of considerable scholarly attention [1-5] and public policy initiatives [6-9]. In particular, policy makers are concerned about a shortage of individuals trained for engineering and other STEM professions. Indeed, interest in generating a skilled labor force underlies much of the research on STEM fields [10,11].

The economic impact of the two and a half million engineers currently employed in the US far surpasses their numbers. Working in diverse industries, they plan roads, bridges and weapons systems for the government, design new products for consumers, monitor and improve production processes in manufacturing and energy production, and develop materials for use in construction, medicine, and many other fields [12,13].

Sociologists have long been interested in engineering [14] due to its status as a profession often based in large corporations [15] and for its role as an exemplar of the knowledge society [16]. In more recent years, the gender and racial homogeneity of practitioners has taken center stage among 
sociologists interested in engineering $[17,18]$. Indeed, engineering is the largest of the STEM majors and is the career most often mentioned by male freshmen [19]. The under-representation of women and minorities is particularly notable in the case of engineering [20].

Examining occupational choices among parents and children will help us to understand the under-representation of women in this field. Research on the determinants of women's entry into the field of engineering has paid relatively little attention to parent's employment in engineering [21]. Sikora and Pokropek (2012) represents a notable exception. If sons are more likely than daughters to follow their fathers into engineering, this differential would contribute to women's under-representation in engineering. Similarly, if daughters are more likely to pattern themselves on their mothers, and if mothers are substantially under-represented in engineering, then this gender-specific role-modeling pattern could contribute to young women's continuing under-representation in this important field. These are among the possibilities we investigate [21].

In addition to contributing to our understanding of diversity in the field of engineering, this study promises to contribute to our understanding of gender patterns within families. By examining gender-specific role models, and investigating whether the salience of mothers' careers has increased over time as women's careers have become more established, we hope to shed light on the way gender inequality is reproduced and how these patterns may be evolving over time. The large and unique data set we tap provides unparalleled opportunity to assess change over time and to make detailed distinctions, such as differentiating between families in which both parents are employed as engineers and those in which only the mother is an engineer.

Understanding freshman plans to pursue a career in engineering should be understood as representing one point in the career-development process. Engineering, along with other STEM fields, experiences considerable attrition during the undergraduate years, and significant gender differences in persistence continue to be evident [22-25].

This line of research often focuses on the scientific "pipeline," that is, stages in the educational career where women may "leak out" of pathways towards a career in engineering [26-28]. For the purposes of understanding the career plans of college freshmen, engineering is a useful case in part because there is a clear link between the choice of field of study in college and the pursuit of a career. Specifically, freshmen who express an interest in pursuing a career in engineering also are likely to plan to major in engineering [29]. In many cases, there is an additional behavioral step involved. In other words, engineering is often located in its own collegiate division or school and frequently requires a separate application process. In short, the plan to pursue a career in engineering represents more than checking off one box in a list of possible careers. We will examine the issue of the predictive validity of freshman career intentions in more detail below.

Finally, given its reliance on data spanning several decades, this study will help us understand change over time. We are particularly interested in exploring whether the salience of mothers in their children's career choices has grown over time.

\section{Scarcity of Studies of Occupational Inheritance}

Researchers from several distinct disciplines have approached the question of occupational assortment using a variety of theoretical frameworks. As we will see, researchers have often focused on self-selection into occupational types or clusters rather than individual occupations. This pattern is evident in both social-psychological studies $[30,31]$ as well as research on social mobility conducted by sociologists [32].

This psychological literature, for example, emphasizes the role of personality and values in the choice of occupations as well as the persistence in these careers. Another approach to intergenerational inheritance employs occupational indices such as prestige scales or socio-economic status scores [33]. 
Similarly, economic studies have generally emphasized intergenerational connections with respect to income rather than via specific occupations per se [34,35]. ${ }^{1}$

There is a widely dispersed literature on the recruitment and retention of employees in particular occupations [36-38]. These fields often come to be studied because of perceived shortages, high turnover, or the belief that the unique demands of a particular field require a very specific personality type. These occupation-specific studies typically do not focus on the inter-generational association. The main exceptions have been volunteers for military service [39] and self-employment. A variety of studies have found that children whose parents were self-employed are much more likely to be self-employed themselves $[40,41] .^{2}$

The scarcity of research on intergenerational connections to particular occupations may well be due in part to the large amount of data needed to pursue this issue, since individual occupations often represent one percent or less of a sample. Fortunately, the UCLA Higher Education Research Institute (HERI) freshman surveys are large enough to allow for the analysis of small but important subgroups.

The questions investigated in this study most closely match those examined in an exemplary paper by Sikora and Pokropek (2012) [21]. They considered the impact of parents' careers on children's plans to pursue STEM careers using data on fifteen-year-old students from 24 countries. The differences between our study and theirs include the following: (a) their study does not focus on engineering alone but groups this field with computer science and mathematics; (b) we are able to examine changes over time in the relationships between parents (especially mothers) and children; (c) our results pertain to college freshmen, who are several years older than the students included in Sikora and Pokropek's study. Not only are college freshmen older and more focused on their career plans, but we are observing them at a particularly critical time in the selection of their field of study.

\section{Theorizing Intergenerational Connections}

It should be noted that there is a broad cultural emphasis on the importance of young adults making their own choices. In other words, parents (at least in the US) are broadly enjoined from issuing specific career directives for their children. Instead, parents' role is often seen as "guiding, not deciding" for their children [42]. ${ }^{3}$ Advice columnists and parenting guides urge parents to help their children pursue opportunities for self-discovery and appropriate information rather than direct them toward a goal of the parents' choosing [43]. In fact, as we will see, the vast majority of children pursue careers that differ from those of their parents.

There are nevertheless a number of reasons to believe that children will be disproportionately likely to follow in their parents' footsteps. There are at least three sources of a connection between the careers of parents and their children: familiarity, values and skills. The world of work is comprised of a bewildering array of specialties, and consequently there are many fields of work which may not be familiar to the average 18-year-old. In general, children are exposed to their parents' career choices, although they may not be acquainted with the details of the job. If occupational choices are disproportionately concentrated among familiar fields, and if children are at least acquainted with their parents' jobs, then children will disproportionately express an interest in the same career choices as their parents. In Sorensen's (2004) memorable formulation, exposure (to parent's occupational experiences) leads to social closure, that is, a tendency for in-group members to have advantaged access to a social position over out-group members [41].

\footnotetext{
Several economic studies of intergenerational inheritance in specific occupations are discussed below.

Self-employment across generations is a complex matter, as not all children take over their parents' business. Moreover, many self-employed individuals are supplementing other family income by working part-time.

3 Parents of students at the University of Minnesota divided roughly between those who felt parents should have "some" influence over their children's career choices $(45 \%)$ and those who felt that parents should have "a little" or "very little" influence (49\%) (University of Minnesota, 2011). Very few parents maintained that they should have "a lot" of influence (less than $2 \%$, and only a small fraction felt that parents should have no influence (less than $4 \%$ ).
} 
Children may also absorb occupationally-related values from their parents. For example, some parents may emphasize the importance of service as a necessary component of meaningful work, while others may stress the importance of job security or pecuniary success. Many studies have documented the inter-general congruence of connection of values, although the connections are sometimes weaker than one might expect and the pathways can be hard to pinpoint [44-47].

A final reason for expecting children to follow in their parent's footsteps relates to the acquisition of skills. Children may absorb some of the 'tricks of the trade' by watching their parents work and listening to their parents' stories. This mode of human capital acquisition has been emphasized for self-employment and family farms, where children are likely to have direct exposure and even involvement, a form of on-the-job training. Some researchers find that those who have inherited occupations from their parents earn more than those whose parents were employed in different fields ([48]; but see Sorensen (2004) for an exception [41]). They attribute this earnings advantage to the assimilation of occupation-specific skills during childhood and adolescence by those who follow in their parents' footsteps.

To summarize, despite a general cultural emphasis on the importance of individual choice, we expect that children are likely to disproportionately select their parents' current career as their own occupational goal.

\section{Engineers' Job Satisfaction}

The tendency of children to follow their parents' career choices assumes that the parents themselves have a generally positive view of their career choices. While it is difficult to summarize feelings about the engineering profession, since it represents such a large and diverse set of careers and employment settings, there are nonetheless several reasons to believe that parents convey a generally positive assessment of their careers in the field.

Professionals tend to view their careers in a favorable light, and engineers are no exception in this regard [49]. Our analysis of job satisfaction using data from the General Social Survey (GSS) reveals that engineers are not statistically distinguishable from other professionals in their level of job satisfaction. ${ }^{4}$

When the Gallup organization asked respondents what kind of work or career they would recommend to a young man or woman, engineering ranked in the top 7 for both genders, and combining "engineering" with "technology/electronics" and "computers" would place this cluster of fields second only to medicine [50]. One survey reports that engineers generally regard their work as "interesting and rewarding" (77\%), and that $84 \%$ would recommend and engineering career to their child or to a friend's child [51].

An additional consideration that should be noted here is that parents of college freshmen are generally older, and job satisfaction increases with age. This is due in part to the fact that job rewards increase with age [52]. It is also the case that parents who are engineers when their children are in college represent those who have survived or persisted in the field of engineering. Many of those who were disgruntled or unsatisfied with engineering would have left the field by this stage in their lives [53]. Since parents of college freshmen are generally in their forties or fifties, they may well offer a more positive evaluation of the field than those who were dissatisfied and left to pursue other lines of work.

4 The main caveat here is the small sample size, due to the fact that job satisfaction is not included in every administration of the GSS, and the fact that only a small fraction of working Americans report that they are employed as engineers. We conducted the comparison for the 53 engineers in the GSS sample as well as for a broader set of architects, engineers and scientists $(n=96)$. 


\section{Fathers and Mothers, Sons and Daughters}

Thus far, we have reviewed reasons for parental effects without differentiating between fathers and mothers on the sending side and sons and daughters on the receiving side. Now, we turn to the issue of gender-specific connections. The father-son relationship has been the focus of the greatest attention. In our view, this reflects the historical assumption that the status of the family depends on the father's occupation and earnings. In other words, if the male is assumed to have the breadwinner role [54], the connection between fathers and sons is the key association in terms of intergenerational transmission of status.

Research on intergenerational social mobility has most commonly taken father's occupation as a measure of 'social origins,' whether or not daughters are included along with sons in the research [55], despite substantial evidence that mothers also influence children's outcomes. When mothers are added to the model, their influence has usually been conceptualized as rooted in their education rather than their occupation (see [56] for a review, and [57] for an exception). However, women's employment has grown to the point that the majority of mothers work for pay, including mothers of pre-school children [58]. The vast majority of undergraduates are able to list a career for their mothers, and only a minority list their mother's occupation as "homemaker." In this context, it is important to develop specific hypotheses regarding the effects of both fathers and mothers on the career choices of sons and daughters.

We expect the occupation-specific father-son connection to be stronger than the father-daughter connection. Daughters who choose to follow their fathers must overcome gendered stereotypes about careers in engineering and science (see $[17,25]$ cited above). In other words, we expect that it will be easier for sons to follow their fathers because there are a host of social and cultural obstacles in the way of daughters who may be inclined to do the same.

The voluminous literature on role models suggests a mother-daughter connection. Researchers have long suggested a connection between positive maternal role models and daughters' engagement in paid employment [59]. ${ }^{6}$ Now that mothers' employment is common, we expect that mothers will not only represent a model of employment but of specific occupational choices as well. More recent research, in both experimental and natural settings, has provided evidence that non-familiar female role models, serve to counter gender-stereotypes [61]. A central question, then, is whether the presence of a significant role model within the family in a gender-atypical setting effectively counters the broader cultural barriers to the daughter's pursuit of a male-dominated field, in this case a career in engineering.

Sikora and Popropek [21] lay out the role-modeling thesis in detail with respect to careers in sciences. They find that role models are influential in the choice of scientific careers, and parents in particular serve as powerful role model.

Marks [62] carefully maps out several specific gender-specific role-modeling effects. Specifically, he investigates whether fathers have stronger effects on boys in terms of the influence of the fathers' socio-economic level, occupational status and educational attainment. The mother-daughter association for these same three factors are also posited to be stronger than the gender-discordant relationships. Drawing on data covering over 170,000 15-year-old students in 32 countries, Marks finds some evidence of these gender-specific relationships on children's student performance, but these associations are not consistently evident within countries or across countries. Marks concludes that it makes relatively little difference which parent contributes resources to the family as long as the mother works for pay. He also finds no evidence of change over time in the impact of mothers relative to fathers.

5 In the 2015 HERI survey, $15.0 \%$ of freshmen listed their mother's occupation as "homemaker/stay at home parent" while $2.0 \%$ of fathers were classified this way. See Eagan et al. [19].

6 See Gerson [60] for a useful corrective to an overly simplistic view of stay-at-home or working mothers as role models. 
Rather than abandon the premise of gender-specific role models, this study will pursue these questions in terms of a substantively different parent-child connection. We posit that that the parent-child connection may well be stronger in terms of the child copying the parent's specific occupational field rather than in terms of students' overall educational performance. The general socio-economic relationships that Marks investigates are rather diffuse and children may not differentiate between their father's and their mother's attributes in this particular way. In other words, if children experience their family's overall social standing as a whole, it may not always be possible to tease out separate effects of mothers and fathers, especially as parents are increasingly matched on their educational levels [63]. In contrast, the particular occupational and career experiences of parents may well be more salient and not reducible to a general socio-economic dimension. Thus, there is reason to believe that, when it comes to career choice, sons may be more likely to copy their fathers while daughters copy their mothers.

In addition to redirecting the question to occupational specific connections, we reframe the question in terms of change over time. Mothers' impact on the career goals of their children may be more salient today than was the case a generation or two ago, when fewer mothers worked outside the home for pay, and when commitment to a full-time career was less common than it has become.

As women spend a greater portion of their lives in the labor force, it may be that their occupational choices are becoming increasingly influential in their children's development of career aspirations. Consequently, we expect that the salience of mothers' careers may well have increased over time, especially in terms of their connection with the career choices of their daughters. We expect that mothers will have disproportionate effect on their daughters rather than their sons, and that the effect on both sons and daughters will have grown in recent decades.

It should also be noted that mothers who remain employed as engineers by the time that their daughters are entering college are a selected group. There is evidence of attrition from engineering at all stages, from the point of college entry and continuing throughout the career, and exit rates are higher for women than for men (see [23-25,53]). Consequently, the role-modelling of mothers in this case needs to be understood against this backdrop. In other words, the mothers who survived in engineering are more likely to be committed to this career, and their daughters are likely to be cognizant of this fact.

In this regard, our hypothesis is quite different than that developed by Hellerstein and Morrill [64], who find evidence of an increasing association over time between the career choices of daughters and their fathers. They posit that this reflects a greater level of "occupational-specific" human capital investments on the part of fathers in the context of a greater likelihood that their daughters are going to spend a significant portion of their careers in the labor market. It is possible, then, that the Hellerstein-Morrill effect may off-set a potential increase in the mother-daughter connection. Of course, it is possible as well that there has been an increase in both the father-daughter and mother-daughter connections. We revisit the Hellerstein-Morrill issue with data that spans the period during which mothers' labor force attachment was increasing.

\section{Parental Occupational Homogamy}

One important consideration in assessing the potential impact of mothers who are engineers is the fact that a very large fraction-almost half-of students whose mothers are engineers also report that their fathers are engineers. Consequently, a simple assessment of the mother's impact on her children will overstate her influence because in many cases this will actually represent the combined effect of fathers and mothers. Because we have such a large sample, we are able to separate engineering families into those which are father only, mother only, or both parents.

\section{Research Questions}

The specific goals of this study include efforts to answer a series of inter-related research questions: 
Research Question 1: Is there an increased likelihood of planning a career in engineering if one or more of the respondent's parents is an engineer?

Research Question 2: Does the association between parents' and children's careers vary for fathers and mothers, and sons and daughters, as well as the case in which both parents are engineers?

Research Question 3: Have these associations increased or declined over the last four decades?

Research Question 4: Are parental effects mostly mediated by particular pathways, such as values and preparation, or is most of the parent-child association a largely unexplained residual?

\section{Data and Methods}

Our research taps into data collected by the Cooperative Institutional Research Program (CIRP), a nationwide study of college students housed at the Higher Education Research Institute at the University of California, Los Angeles. The HERI Freshman Survey, a national longitudinal study of college students in the United States, annually obtains responses from entering college students regarding their demographic backgrounds, high school experiences, affective traits such as self-concepts and values, and goals and aspirations related to college and beyond.

Data for this study cover the period 1976 through 2011. The analysis reported here is based on a sample of nearly 1 million first-year students. This sample is stratified by institutional type, control and selectivity. Weights are applied in order to make the results representative of freshmen enrolled full time at four-year institutions in the United States [19].

Entering freshmen are asked to indicate their intended career as well as the careers of their parents based on a list of several dozen career goals on the survey. This occupational list forms the basis for the dependent variable in this study as well as the two key independent variables. Students who designated "engineer" as their career goal were assigned a value of 1 ; other occupational plans were assigned a value of 0 . The same procedure was applied to students' reports of the parents' occupations. The odds ratios for father-son, father-daughter, mother-son and mother-daughter associations are calculated. These and other analyses are reported separately by gender. The trends in these associations are also reported.

Once the associations between first-year students' plans to enter engineering and their parent's employment in engineering were established, we sought to identify whether these associations were mediated by identifiable measures. In other words, we examined whether the parent-child association could be explained by factors such as academic self-concept or student values, or whether the association was a direct one, net of mediating factors. We employ logistic regression analysis, given the $0 / 1$ nature of the dependent variable. We also checked on the robustness of the model by re-estimating it with OLS (ordinary least squares) regression as recommended by Mood [65].

The control variables employed in this study were prepared as part of a larger project on the determinants of majoring in STEM fields. The selection and grouping of other independent variables draws on Lent, Brown, and Hackett's [66] Model of Career Related Choice Behavior (MCRCB). Variables were divided into four groups:

- Race, Ethnicity and Religion

- Socio-economic Characteristics

- Educational Preparation, Self-Rated Abilities and Aspirations

- Personality, Interests and Goals.

- Race, Ethnicity and Religion: Race dummy variables (vs. White) include African-American, Asian-American, Latino/Chicano and Native American. Religion (versus Protestant) dummy variables include Catholic, Jewish, Other and None.

- Socio-economic Characteristics: Family Income, Mother's and Father's Education, Race, Ethnicity and Religion, and Financial Concern for College, 
- Academic Preparation, Self-Rated Abilities and Aspirations: High School GPA, Self-rated Mathematics Ability, Scholar Personality (factor), Degree Aspiration, Expectation of Making at Least a B Average, Expectations of Changing Major Field, Educational Reasons for Going to College (factor).

- Personality, Interests and Goals: Leader Personality (factor), Scholar Personality (factor), Goal of Making a Theoretical Contribution to Science; Goal: Developing a Meaningful Philosophy of Life; Goal: Raise a Family; Social Activist Personality (factor), Artistic Personality (factor), and Status Striver Personality (factor), Educational Reasons for Going to College (factor), Extrinsic Reasons for Going to College (factor).

The principal focus is the effect of these blocks of variables on the strength of the parent-child connection. The goal of the analysis is to determine whether these groups of variables account for, or explain, the impact of parents on their child's choice of engineering as a career goal. The construction of the factors and other specifics regarding these control variables can be found in the appendix section of this paper.

While we draw on a very large data set spanning a long period of time with an extensive set of variables, there are limitations to this study, as is inevitable in any research of this kind. The data we examine do not follow students over their undergraduate years and into their careers. Thus, while we are able to shed light on a key moment in the career development process, we are unable to address questions regarding persistence into engineering and other STEM careers. The UCLA HERI Freshman Survey data also do not include questions regarding how involved parents are in their children's career choices, questions that are available in some other studies, e.g., [67]. We also do not have direct measures on parents' values. We are thus in a position of inferring value transmission from student reports rather than comparing students' and parents' reports.

\section{Results}

Figure 1 displays trends in the percent of freshmen indicating that they plan to major in engineering. For most of the last forty years, these figures have hovered between $12 \%$ and $18 \%$ for men and $2 \%$ and $4 \%$ for women. The fraction of women indicating an interest in engineering has increased since the 1970 s, when it was $12 \%-13 \%$ as high as men's, ${ }^{7}$ it has ranged from $18 \%$ and $22 \%$ of men's level of interest since then. ${ }^{8}$

Are sons of engineers more likely to follow their fathers into engineering, and daughters more likely to follow their mothers? Pertinent data are presented in Table 1. Summarizing over the entire period 1976-2011, the findings indicate that a significant minority of sons of engineers (27.4\%) plan to follow their fathers into this career field, compared with $13.3 \%$ of their male classmates.

A brief discussion of probabilities, odds and odds ratios may be helpful in understanding these patterns. The probability of a young man aspiring to engineering if his father is an engineer is 27.4. The odds of his aspiring to engineering if his father is an engineer is $27.4 / 72.6=0.377(\mathrm{p} / 1-\mathrm{p})$. For young men whose fathers are NOT engineers, the corresponding odds are 13.3/86.7 $=0.153$. The odds ratio for young men with and without engineering fathers is therefore $0.377 / 0.153=2.46$, meaning that those with an engineering father are $146 \%$ more likely to aspire to an engineering career than those without an engineering father.

While daughters are much less likely to plan to become engineers than are sons, there is nonetheless an increased likelihood associated with parental employment in this field. Daughters

7 For example, in 1976, 1.93\% of women and 14.99\% of men planned a career in engineering; thus, women's level of interest was $13.4 \%(1.93 / 14.99=13.4 \%)$ as high as men's.

8 Figure 1 indicates an increase in interest in engineering careers on the part of both freshman men and women that coincided with the start of the Great Recession. This increase is also reflected in a growth in the number of engineering majors and enrollment in schools of engineering [68]. 
whose fathers or mothers are engineers are more likely to enter engineering $(6.3 \%$ and $11.9 \%$, respectively), than are those whose parents are engaged in other occupations and professions $(2.3 \%-2.6 \%)$.

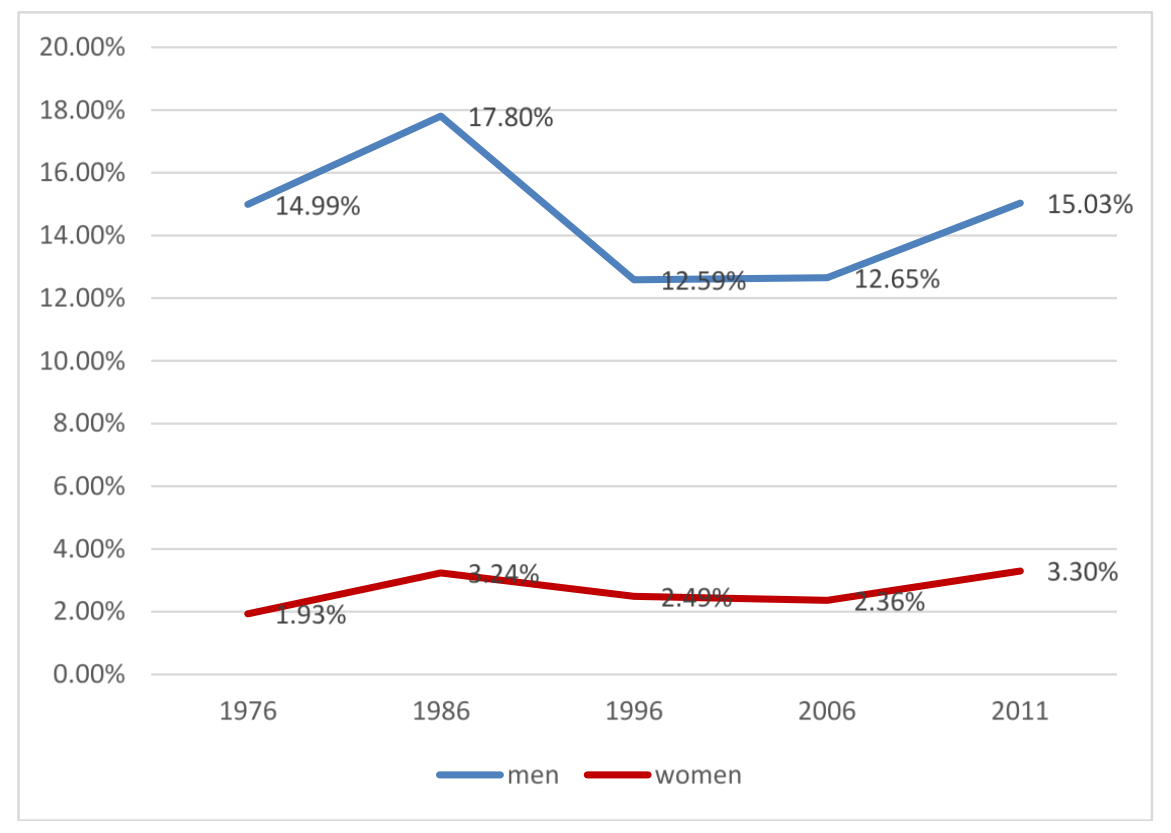

Figure 1. Percent of College Freshman Planning to Become Engineers.

A more comprehensive assessment of the parent-child association can be obtained with odds ratios, which compare the rates for the children of engineers with those of other freshmen. For all four parent-child relationships, there is a considerable effect of parents' careers on their children's choices. Expressed in terms of an odds-ratio, the odds of entering engineering more than double (2.45) if the father is an engineer.

A strong father-daughter connection appears when this association is depicted in terms of an odds ratio (2.85). This does not mean that daughters of engineering fathers are more likely to become engineers than male counterparts. Rather, it indicates that the relative effect of fathers (starting at a very low baseline) is as large if not larger for daughters than for sons. The mother-daughter connection appears to be the strongest of all of the parent-child dyads (odds ratio $=5.06$ ), but further analysis is needed to refine this conclusion. The gender-specific associations conform to our expectations in some respects but not in others. The main surprise is the disproportionately large effect of mothers on both their sons and daughters. As we will see shortly, this effect is not quite what it seems, as it is in part a "both-parents" effect.

The unstated pattern in the first panel of Table 1 is the fact that many mothers who are engineers have spouses (or at least co-parents) who are also engineers. While of course not all parents are married or remained married by the time their children enter college, understanding the impact of parental occupational homogamy is necessary for fully addressing the issue of gender-specific role-modeling. Overall, $8.5 \%$ of all freshmen have only a father who is an engineer, $0.5 \%$ only have a mother who is an engineer and $0.24 \%$ report that both parents are engineers. There is an interesting asymmetry in mothers' and fathers' engineering careers. Nearly half of students who report that their mothers are engineers also report that their fathers are engineers $(47.2 \%)$, while only a small fraction $(2.8 \%)$ of students with engineering fathers report having a mother who is an engineer. ${ }^{9}$ This reflects the 
fact that women engineers represent such a small minority in this profession. This asymmetry will reappear in interpreting other findings as well. This pattern of occupational homogamy among parents requires us to separate out parents into four categories: the (a) father is an engineer while the mother is not; (b) the mother is an engineer while the father is not; (c) both parents are engineers; and (d) neither parent is an engineer.

Table 1. Interest in Engineering by Parental Engineering Employment and Gender.

\begin{tabular}{|c|c|c|c|}
\hline A. Sons & & & \\
\hline \multicolumn{4}{|c|}{ percent indicating engineering as a career plan } \\
\hline father & father not & mother & mother not \\
\hline engineer & engineer & engineer & engineer \\
\hline 0.274 & 0.133 & 0.305 & 0.145 \\
\hline \multicolumn{4}{|l|}{ B. Daughters } \\
\hline \multicolumn{4}{|c|}{ percent indicating engineering as a career plan } \\
\hline father & father not & mother & mother not \\
\hline engineer & engineer & engineer & engineer \\
\hline 0.063 & 0.023 & 0.119 & 0.026 \\
\hline \multicolumn{4}{|c|}{ C. Sons, Differentiating Father only, Mother only and Both Parents as Engineers } \\
\hline \multicolumn{4}{|c|}{ percent indicating engineering as a career plan } \\
\hline father only & mother only & both parents & neither parent \\
\hline engineer & engineer & engineers & engineer \\
\hline 0.270 & 0.236 & 0.382 & 0.133 \\
\hline \multicolumn{4}{|c|}{ D. Daughters, Differentiating Father only, Mother only and Both Parents as Engineers } \\
\hline \multicolumn{4}{|c|}{ percent indicating engineering as a career plan } \\
\hline $\begin{array}{l}\text { father only } \\
\text { engineer }\end{array}$ & $\begin{array}{l}\text { mother only } \\
\text { engineer }\end{array}$ & $\begin{array}{l}\text { both parents } \\
\text { engineers }\end{array}$ & $\begin{array}{l}\text { neither parent } \\
\text { engineer }\end{array}$ \\
\hline 0.060 & 0.077 & 0.165 & 0.023 \\
\hline
\end{tabular}

The effect of fathers on their sons and daughters declines slightly when the association focuses on families in which only the father is the engineer. (The odds ratio declines from 2.45 to 2.38 for sons.) This slight change is due to the fact that a small number of "both parent" engineering families are included in the results reported in Panel A of Table 1. When this group is removed, the father-son relationship declines marginally. There is much more sizable decline in the mother-son association when dual-engineering families are removed due to the concentration of engineering mothers in this group. The mother-son odds ratio declines from 2.60 to 1.81 when the analysis focuses on mothers only.

The same pattern holds for daughters. There is still a considerable father-daughter connection Panel D of Table 1 (odds ratio is 2.65), but the effect of mothers on daughters is considerably attenuated (odds ratio $=3.08$, compared with 5.06 when dual-engineering parents are included).

When both parents are engineers, the parental effect more than doubles for sons and nearly doubles for daughters. A large minority (38.2\%) of sons plan to pursue engineering when both of the parents are engineers, while for daughters the rate is about one in six $(16.5 \%)$. This rate is roughly the same as what would be obtained by adding the impact of both fathers and mothers. This finding speaks to the power of families to affect the career choices of their children.

The results presented in Table 2 speak to trends over time in parent-child associations. Rather than portraying these connections as reflecting some enduring psycho-social dynamic within families, our analysis opens up the possibility that these relationships vary over time. 
Table 2. Time Trends for Parent Child Association.

\begin{tabular}{|c|c|c|c|c|c|}
\hline \multirow{2}{*}{ A. Sons } & \multicolumn{5}{|c|}{ Odds Ratios } \\
\hline & Father & Mother & Father only & Mother only & Both Parents \\
\hline 1976 & 2.43 & 2.15 & 2.41 & 1.24 & 4.58 \\
\hline 1986 & 2.29 & 1.70 & 2.27 & 1.28 & 2.85 \\
\hline 1996 & 2.35 & 1.98 & 2.31 & 1.47 & 3.01 \\
\hline 2006 & 2.50 & 2.72 & 2.42 & 2.03 & 3.57 \\
\hline 2011 & 2.71 & 3.41 & 2.52 & 2.32 & 4.39 \\
\hline All Years & 2.45 & 2.60 & 2.38 & 1.81 & 3.63 \\
\hline \multirow{2}{*}{ B. Daughters } & \multicolumn{5}{|c|}{ Odds Ratios } \\
\hline & Father & Mother & Father only & Mother only & Both Parents \\
\hline 1976 & 3.22 & 2.21 & 3.19 & - & - \\
\hline 1986 & 2.51 & 2.25 & 2.47 & 1.69 & 5.85 \\
\hline 1996 & 2.53 & 4.14 & 2.42 & 3.09 & 5.75 \\
\hline 2006 & 3.11 & 5.38 & 2.77 & 3.02 & 7.90 \\
\hline 2011 & 3.01 & 5.18 & 2.60 & 3.34 & 6.75 \\
\hline All Years & 2.85 & 5.06 & 2.65 & 3.08 & 7.35 \\
\hline
\end{tabular}

Note: Missing values for 1976 reflect low samples sizes. The 1986 results for mother only and both parents represent an average of 1976 and 1986 data.

In Table 2, we see a steady increase over time in the effect of mothers who are engineers on the career choices of their children. These results are presented graphically in Figure 2a,b. Focusing on the father-only and mother-only trends, for sons, mothers' impact is much weaker than that of fathers at the start of the study period. The gap, however, narrows considerably, and since 2006, the connection between mothers' careers and their sons' career choices is considerable (odds ratios in excess of 2.0 for 2006 and 2011). For daughters, however, the marked increases in mothers' effect now reveal a stronger mother-daughter connection than is the case between fathers and daughters. The mother-daughter association jumped in the 1990s and has remained strong (odds ratios above 3.0) ever since. ${ }^{10}$

The results presented in Table 2 underscore the importance of examining change over time. Specifically, the relative influence of parents on daughters shifts over time. Fathers had more impact than mothers on their daughter's career choices in the 1970s and 1980s, and this pattern shifts to a gender-specific role-modeling pattern since the 1990s.

In the multivariate analyses, we estimated the effect of several sets of variables in addition to parents' occupation on the choice of engineering. In other words, we added groups of variables in order to see how much they reduced the intergenerational associations presented in Tables 1 and 2 . Coefficients for parental engineering status from nested (or step-wise) regression results are presented in summary form in Tables 3 and 4 . The full models are presented in Tables A3 and A4.

Intergenerational effects remain strongest for same-gender parents, and the overwhelming majority of the parent-child association is a direct effect, independent of the mediating variables included in our model. In other words, other indicators of social background, children's academic preparation and values, self-efficacy, etc., are responsible for only a small portion of the parent-child association observed. This pattern is particularly clear for fathers and sons, where nearly $90 \%$ of the association remains after controls are added to the model. The pattern also holds almost as well for fathers and daughters.

The influence of mediating variables is stronger in understanding the effect of mothers: roughly one quarter of the father-daughter association is mediated by the control variables, as is nearly

10 The cell sizes for 1976 were too small to report when we tried to differentiate between mother-only and dual-career marriages, but the increasing maternal effect is evident in the overall mother's effect reported in Table 2. The odd-ratio for mothers and daughters grows from 2.21 in 1976 to 4.14 in 1996 to 5.18 in 2011. 
two-fifths of the mother-daughter association. Academic variables such as self-rated mathematics ability and personality, interest and goals play the largest role in mediating the mother-daughter association. This notable results warrants further inquiry.

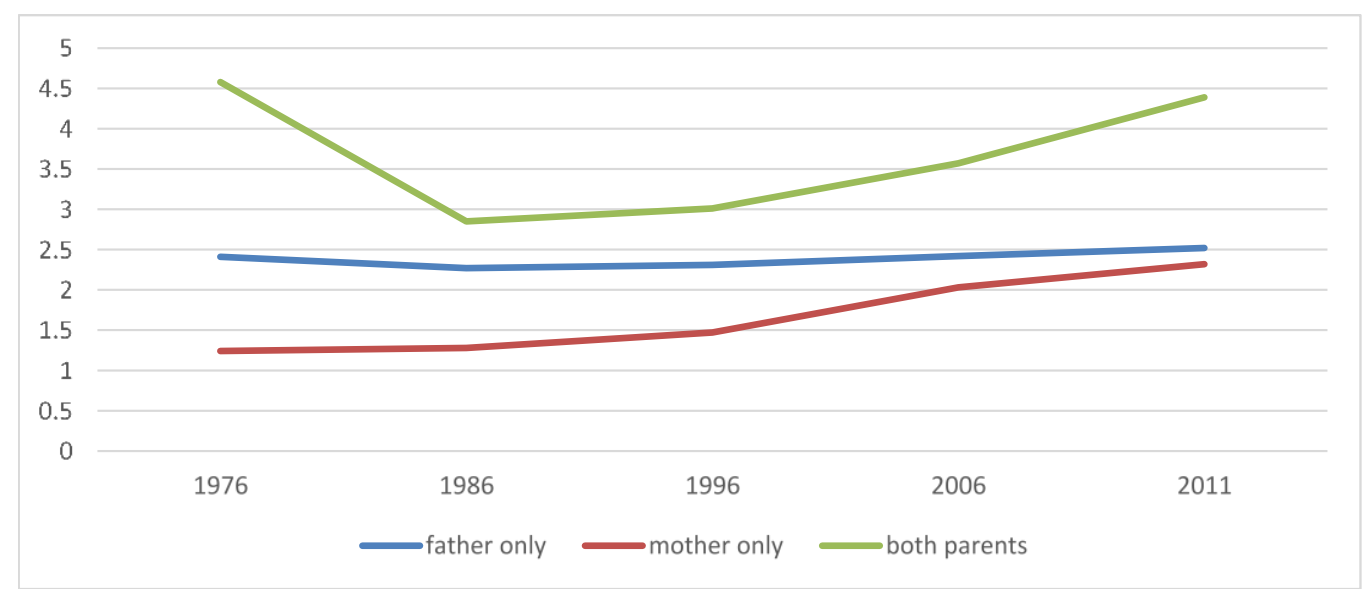

(a)

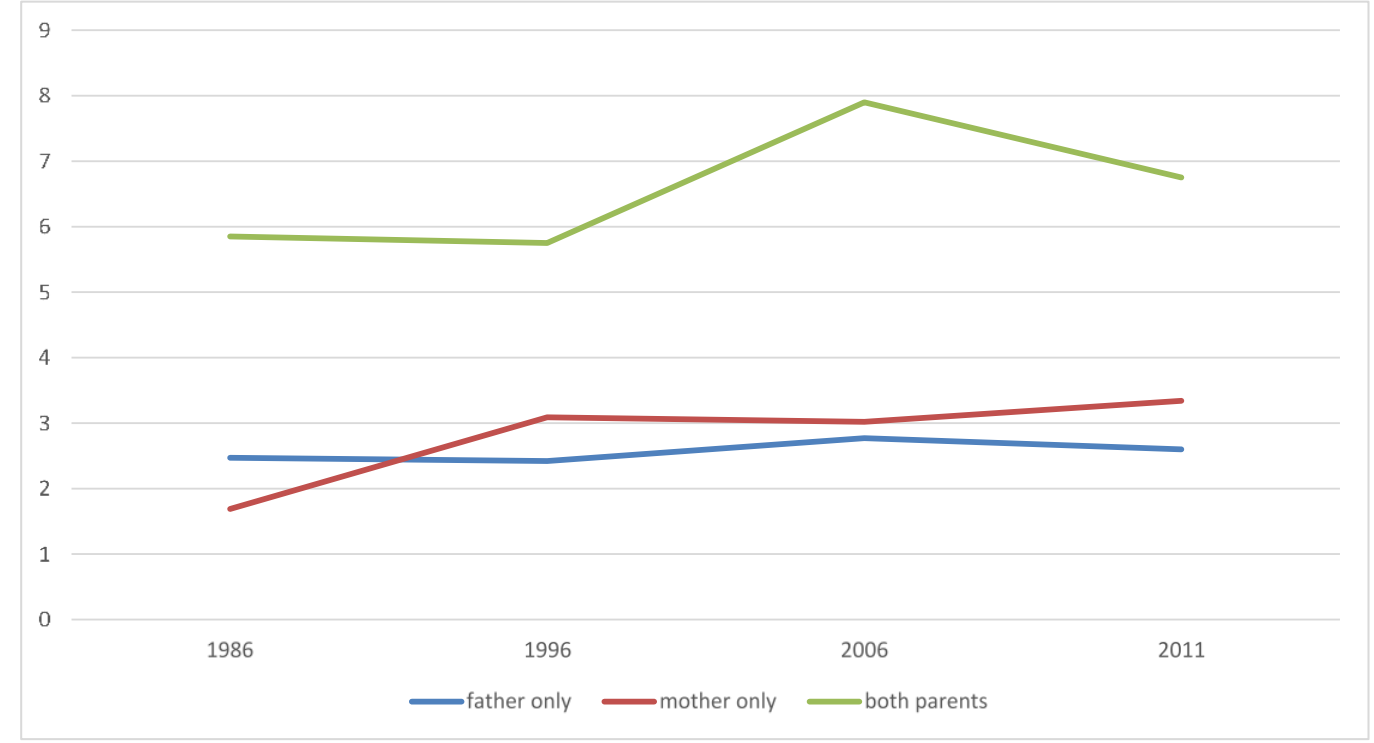

(b)

Figure 2. (a) Trends in Parent-Son Association for Plans to Enter Engineering: Odds Ratios; (b) Parent-Daughter Association for Plans to Enter Engineering: Odds Ratios.

The OLS analysis confirms the general story but there is less of a gendered difference in the effects of the mediating variables (See Table 4). The portion of the intergenerational association mediated by control variables is roughly $20 \%$ for fathers and sons, $25 \%$ for mothers and sons, $15 \%$ for fathers and daughters, and $20 \%$ for mothers and daughters. In both sets of specifications, there is a large intergenerational association not accounted for by the factors controlled in this analysis. The full regression models are reported below as Tables A3 and A4.

The results were estimated separately for freshman men and women. We pooled the two groups in order to test for statistical significance. Given the large sample sizes, the gender differences reported are all statistically significant, $p<0.001$. Specifically, the father-son association differs from the father-daughter relationship, and the mother-son and mother-daughter effects differ as well. 
Table 3. Summary of Logistic Regression Results.

\begin{tabular}{|c|c|c|c|c|c|c|c|}
\hline \multirow{3}{*}{\multicolumn{2}{|c|}{ A. Male Freshmen }} & \multicolumn{3}{|c|}{ Father } & \multicolumn{3}{|c|}{ Mother } \\
\hline & & \multicolumn{3}{|c|}{ Engineer } & \multicolumn{3}{|c|}{ Engineer } \\
\hline & & Coefficient & Std. Error & Odds Ratio & Coefficient & Std. Error & Odds Ratio \\
\hline Model 0 & Father Engineer, Mother Engineer & 0.874 & 0.010 & 2.397 & 0.594 & 0.039 & 1.811 \\
\hline Model 1 & Race, Ethnicity and Religion added & 0.853 & 0.012 & 2.346 & 0.592 & 0.047 & 1.808 \\
\hline Model 2 & Socio-economic Characteristics added & 0.909 & 0.012 & 2.481 & 0.643 & 0.047 & 1.901 \\
\hline Model 3 & $\begin{array}{l}\text { Educational Preparation, Self-Rated } \\
\text { Abilities and Aspirations added }\end{array}$ & 0.866 & 0.013 & 2.378 & 0.582 & 0.050 & 1.790 \\
\hline Model 4 & Personality, Interests and Goals added & 0.798 & 0.014 & 2.220 & 0.533 & 0.053 & 1.704 \\
\hline \multicolumn{2}{|c|}{$\begin{array}{l}\text { Percent Parent Effect Unexplained } \\
\text { (Model 0/Model 4) }\end{array}$} & $91.30 \%$ & & $92.62 \%$ & $89.73 \%$ & & $94.09 \%$ \\
\hline & No. of Cases & \multicolumn{6}{|c|}{748,817} \\
\hline \multirow{3}{*}{\multicolumn{2}{|c|}{ B. Female Freshmen }} & \multicolumn{3}{|c|}{ Father } & \multicolumn{3}{|c|}{ Mother } \\
\hline & & \multicolumn{3}{|c|}{ Engineer } & \multicolumn{3}{|c|}{ Engineer } \\
\hline & & Coefficient & Std. Error & Odds Ratio & Coefficient & Std. Error & Odds Ratio \\
\hline Model 0 & Father Engineer, Mother Engineer & 0.993 & 0.018 & 2.7 & 1.177 & 0.052 & 3.245 \\
\hline Model 1 & Race, Ethnicity and Religion added & 0.973 & 0.022 & 2.645 & 0.962 & 0.061 & 2.618 \\
\hline Model 2 & Socio-economic Characteristics added & 0.927 & 0.022 & 2.528 & 0.914 & 0.061 & 2.493 \\
\hline Model 3 & $\begin{array}{l}\text { Educational Preparation, Self-Rated } \\
\text { Abilities and Aspirations added }\end{array}$ & 0.817 & 0.023 & 2.264 & 0.772 & 0.065 & 2.164 \\
\hline Model 4 & Personality, Interests and Goals added & 0.75 & 0.024 & 2.116 & 0.715 & 0.068 & 2.043 \\
\hline \multicolumn{2}{|c|}{$\begin{array}{l}\text { Percent of Parent Effect Unexplained } \\
\text { (Model 0/Model 4) }\end{array}$} & $75.53 \%$ & & $78.37 \%$ & $60.75 \%$ & & $62.96 \%$ \\
\hline & No. of Cases & \multicolumn{6}{|c|}{885,793} \\
\hline
\end{tabular}

Note: Full Model is presented as Table A3. 
Table 4. Summary of OLS Regression Results.

\begin{tabular}{|c|c|c|c|c|c|c|}
\hline & \multirow{3}{*}{ A. Male Freshmen } & \multirow{2}{*}{\multicolumn{2}{|c|}{$\begin{array}{c}\text { Father } \\
\text { Engineer }\end{array}$}} & \multirow{2}{*}{\multicolumn{2}{|c|}{$\begin{array}{c}\text { Mother } \\
\text { Engineer }\end{array}$}} & Adjusted \\
\hline & & & & & & \multirow{2}{*}{$\mathbf{R} 2$} \\
\hline & & B & Std. & B & Std. Error & \\
\hline Model 0 & Father Engineer, Mother Engineer & 0.137 & 0.001 & 0.107 & 0.004 & 0.013 \\
\hline Model 1 & Race, Ethnicity and Religion added & 0.138 & 0.001 & 0.105 & 0.004 & 0.016 \\
\hline Model 2 & Socio-economic Characteristics added & 0.144 & 0.001 & 0.111 & 0.004 & 0.018 \\
\hline Model 3 & $\begin{array}{l}\text { Educational Preparation, Self-Rated } \\
\text { Abilities and Aspirations added }\end{array}$ & 0.126 & 0.001 & 0.094 & 0.004 & 0.094 \\
\hline Model 4 & Personality, Interests and Goals added & 0.11 & 0.001 & 0.081 & 0.004 & 0.150 \\
\hline \multicolumn{2}{|c|}{$\begin{array}{l}\text { Percent Parent Effect Unexplained } \\
\text { (Model 0/Model 4) }\end{array}$} & $80.20 \%$ & & $75.70 \%$ & & \\
\hline \multicolumn{2}{|r|}{ No. of Cases } & \multicolumn{5}{|c|}{748,817} \\
\hline \multirow{3}{*}{\multicolumn{2}{|c|}{ B. Female Freshmen }} & \multicolumn{2}{|c|}{ Father } & \multicolumn{2}{|c|}{ Mother } & Adjusted \\
\hline & & \multicolumn{2}{|c|}{ Engineer } & \multicolumn{2}{|c|}{ Engineer } & ? \\
\hline & & B & Std. & B & Std. Error & $\mathrm{Nz}$ \\
\hline Model 0 & Father Engineer, Mother Engineer & 0.038 & 0.001 & 0.079 & 0.003 & 0.006 \\
\hline Model 1 & Race, Ethnicity and Religion added & 0.040 & 0.001 & 0.073 & 0.003 & 0.008 \\
\hline Model 2 & Socio-economic Characteristics added & 0.039 & 0.001 & 0.072 & 0.003 & 0.008 \\
\hline Model 3 & $\begin{array}{l}\text { Educational Preparation, Self-Rated } \\
\text { Abilities and Aspirations added }\end{array}$ & 0.034 & 0.001 & 0.065 & 0.003 & 0.041 \\
\hline Model 4 & Personality, Interests and Goals added & 0.032 & 0.001 & 0.061 & 0.003 & 0.060 \\
\hline \multicolumn{2}{|c|}{$\begin{array}{l}\text { Percent Parent Effect Unexplained } \\
\text { (Model 0/Model 4) }\end{array}$} & $84.20 \%$ & & $77.20 \%$ & & \\
\hline & No. of Cases & \multicolumn{5}{|c|}{885,793} \\
\hline
\end{tabular}




\section{Persistence in Engineering}

A skeptic might question whether freshman intentions are a meaningful indicator of the choice of major and career. While many students who report engineering as a career goal will not end up as engineers, the freshman data are more predictive than a questioning reader might assume. Moreover, if there is one field where the link between freshman intentions and career outcomes is likely to be evident, it would be the field of engineering. Many students enter the engineering pipeline early because the extensive and demanding requirements can make switching in relatively difficult. In fact, nearly all students who report planning to become an engineer also report that engineering is their intended field of study ( $95 \%$ of men and $94 \%$ of women). Thus, engineering career plans have face validity in terms of their connection to the choice of major.

A variety of data sources also suggest substantial persistence; that is, students who plan to major in engineering are well represented among those who graduate with engineering degrees and begin their careers as engineers. Astin and Astin (cited as [22] above) report that $43.9 \%$ of freshmen who intended to major in engineering in 1985 remained in the field four years later, and a total of $53.4 \%$ ended up in a STEM field. While this may seem to indicate a low rate of persistence, it should be noted that relatively few students switch into engineering. In other words, over two-thirds $(68.9 \%)$ of those who were majoring in engineering in 1989 had planned to do so four years earlier. Expressed in terms of an odds ratio, students were 33 times more likely to become an engineering major if they had indicated this plan as a freshman.

A strong pattern of persistence of freshmen in engineering is also reported with more recent data by Hughes and his colleagues ([29] above). They also found that having a parent who was an engineer increased the chances of completing this course of study. In other words, having a parent who was an engineer not only increased the chances of entering engineering, but also increased the chances of continuing in the field. Sax [70] reports that the majority of engineering undergraduates who pursued graduate training ( $64.9 \%$ of women and $63.5 \%$ of men) did so in the field of engineering.

While the persistence data discussed here may seem to set a higher bound on the degree of parental impacts, there are a number of additional considerations that should be taken into account. It may be that some children of engineers who did not express an interest in the field reverted to this choice at some later point. As noted above, nearly one-third of engineering graduates switch into the field during college. If children of engineers are disproportionately represented in this group, it would increase the degree of intergenerational connection.

Another consideration has to do with near misses. It is often the case that children are affected by their parent's occupation even when it is not a case of complete correspondence. For example, if the mother is an electrical engineer and her daughter planned to be a computer scientist, many would consider this a case of the daughter following in her mother's footsteps, but in our analysis, this would be considered a defection [71]; see also [22]. If we add physical sciences and mathematics as additional educational choices and science-related careers, the extent of parental sway would be substantially higher than if the analysis is restricted to perfect matches.

\section{Conclusions}

This study contributes to our understanding of how the scientific and technical labor force is created. Specifically, there is a significant inter-generational association in the pursuit of careers in engineering. Both fathers and mothers significantly affect the career choices of their sons and daughters. These effects are large direct effects, that is, they are principally effects that are in addition to the effects of parents' socio-economic status and the influence that they may have on their children's values. In other words, the parental coefficients remain large even in full model with extensive controls.

Since young women and young men are roughly equally likely to have parents who are engineers, the gender differential in this case is not a matter of daughters' deficit. In other words, the gaps documented here are more about differences in parental effects between young men and young women rather than differences in levels of family resources or family exposure to engineering role models. 
The data point to gender-specific role model effects. Sons are more likely to follow in their father's footsteps than in their mother's. The gender gap in parents' effects has narrowed as the salience of mothers on the career choices of their children has grown over time. The gender-specific role-modeling pattern for daughters is a story of change over time. In the 1970s and 1980s, daughters were more likely to follow their fathers than their mothers. However, since the 1990s, the mother-daughter connection has become stronger than the father-daughter connection. This pattern is most evident when the power of mothers is isolated by distinguishing mother-only engineering families from those in which both parents were engineers. Identifying the small numbers of families in which both parents are engineers reveals the powerful role modeling that occurs under such conditions.

Our results extend the findings of Sikora and Propokek [21] by showing that gender-specific parental role modeling operates at the point of college entry. The findings extend Marks's [62] analysis by examining occupation-specific role modeling effects. In other words, while the general socio-economic standing of mothers and fathers does not consistently appear to be channeled via gender-specific role modeling, the choice of specific occupations does operate in this manner. The results presented here run somewhat counter to those of Hellerstein and Morrill [64], in that it is the growing importance of mothers rather than fathers that stands out.

The daughters of engineers are much less likely than are sons to pursue careers in engineering. This gendered baseline is clear from the data, even though the presence of parents in the field leads daughters to pursue engineering far more than the classmates in non-engineering families. One potential source of additional women in engineering (and, by extension, other STEM fields) would be to increase their representation to the same level as their brothers and other male counterparts.

The results point to a growing effect of mothers on the career choices of their children, especially their daughters. We interpret this as pointing to a growing salience. The presence of mothers in the labor force is now more established, and mothers are working for a greater share of their children's early years. The evidence from engineering, which remains a majority-male field, brings the influence of mothers' careers into sharp relief.

The findings on the increasing impact of mothers on daughters is a promising development, but (a) engineering mothers remain relatively scarce, and thus the payoff of this relationship will take a long time to have a significant impact; and (b) the growing significance of mothers is relative to the low baseline of daughters' interest in engineering. In other words, while the impact of mothers is now considerable, the level of their daughters' interest in engineering continues to lag well behind their male counterparts.

Do the findings on the salience of parents' careers point to any policy recommendations for non-engineering families? Compared to students whose parents are engineers, other students have less direct exposure to the profession, less familiarity with the values and lifestyle that this type of career involves, and possibly less occupation-specific knowledge. Consequently, more effort to cultivate interest in engineering in these families is likely to be required.

The notion of gender-specific role models may perhaps be extended from the realm of family members to non-family members. Projects engaged in promoting women's representation in engineering [72] have tried to develop social supports in just this way. In other words, if students have not had direct exposure to engineering and related STEM fields in their own family experience, educators can seek to substitute other social experiences that would provide a substitute for this type of direct familiarity and exposure. The data reported here are consistent with the thrust of this type of non-familial social supports are in order for the great majority of college students who did not happen to have parents who spent their careers in the engineering profession.

Acknowledgments: This research is supported by the National Science Foundation, HRD \#1135727.

Author Contributions: Linda J. Sax was the Principal Investigator on the National Science Foundation research project a portion of which is reported in this paper. She conceptualized the research design and led the data-preparation and variable construction efforts. Seher Ahmad conducted the majority of the data analysis on this paper, and Jerry A. Jacobs did the majority of the writing. 
Conflicts of Interest: The authors declare no conflict of interest.

\section{Appendix A. Details on the Multivariate Regression Analysis}

This study utilizes data from the Cooperative Institutional Research Program (CIRP) Freshman Survey, the oldest and largest longitudinal study of American higher education. The survey is administered to entering college students and covers a wide range of topics, including demographic background, high school experiences, college expectations, self-concepts, values, and life goals as well as their academic and career aspirations. A large number of these variables have been asked consistently over the years; hence, this information enables us to meet the study's key objectives, which is to examine changes over time in parent's influence on the pursuit of a career in engineering.

This study is based on CIRP data from 1225 baccalaureate-granting institutions from 1976 to 2011. Data on five time points (1976, 1986, 1996, 2006 and 2011 are included. The trend analysis explores how the intent to pursue a career in engineering has varied by gender from 1976 to 2011. The sample for the descriptive trend analysis was then weighted by student gender and institutional control, type, and selectivity so that it would reflect the population of first-time, full-time college students at all four-year institutions in the United States for each year. (See Pryor et al. [65], for a weighting scheme, in addition to validity, and reliability).

The regression analyses provide insight into the pathways which may account for parents' effect on their children's plans to pursue a career in engineering, and focus on five specific years of survey data: 1976, 1986, 1996, 2006, and 2011. These years were selected because they contained the most consistent set of survey items at evenly-spaced decade (and one half-decade) intervals. The regression sample from across these five years is unweighted.

\section{Measures}

Men's and women's self-reported plans to pursue a career in engineering (versus all other majors) serves as the dependent variable in the regression analysis. Planning a career in engineering is coded as 1 and all other career plans are coded as zero. Overall, $14.5 \%$ of the male freshmen and $1.9 \%$ of the female freshmen indicated that they planned to pursue careers in engineering. Given the focus on intergenerational connections, father's and mother's employment in engineering serve as the key independent variables in this analysis.

The list of independent variables used for the regression analysis, along with their coding schemes, is provided in Table A1.

Table A1. Variable List and Coding.

\begin{tabular}{|c|c|}
\hline Dependent Variables & \\
\hline Intent to Puruse a Career in Engineering & Dichotomous: $0=$ All others, $1=$ Engineering \\
\hline \multicolumn{2}{|l|}{ Key Independent Varaiables } \\
\hline Father Engineer & Dichotomous: $0=$ All Others, $1=$ Engineering \\
\hline Mother Engineer & Dichotomous: $0=$ All Others, $1=$ Engineering \\
\hline \multicolumn{2}{|l|}{ Race, Ethnicity and Religion Race (vs. White) } \\
\hline African American & Dichotomous: $0=$ "No", $1=$ "Yes" \\
\hline Asian American & Dichotomous: $0=$ "No", $1=$ "Yes" \\
\hline Latino/Chicano & Dichotomous: $0=$ "No", $1=$ "Yes" \\
\hline Native American & Dichotomous: $0=$ "No", $1=$ "Yes" \\
\hline Religion: Catholic & Dichotomous: $0=$ "No", $1=$ "Yes" \\
\hline Religion: Jewish & Dichotomous: $0=$ "No", $1=$ "Yes" \\
\hline Religion: Other & Dichotomous: $0=$ "No", $1=$ "Yes" \\
\hline Religion: None & Dichotomous: $0=$ "No", $1=$ "Yes" \\
\hline \multicolumn{2}{|l|}{ Socio-Economic Characteristics } \\
\hline Father's Education & 8-point scale: $1=$ "Grammar school or less" to $8=$ "Graduate Degree" \\
\hline Mother's Education & 8-point scale: $1=$ "Grammar school or less" to $8=$ "Graduate Degree" \\
\hline Family Income & 25 -point scale: $1=$ "less than $\$ 6000 "$ to $25=" \$ 250,000$ or more" \\
\hline Concern about Finances & 3-point scale: 1 = "None", 2 ="Some", 3 = "Major" \\
\hline
\end{tabular}


Table A1. Cont.

\begin{tabular}{|c|c|}
\hline \multicolumn{2}{|l|}{ Dependent Variables } \\
\hline \multicolumn{2}{|c|}{ Educational Preparation, Self-Rated Abilities, and Aspirations } \\
\hline High School GPA (Average grade in H.S.) & 8-point scale: $1=$ "D" to $8=" \mathrm{~A}$ or $\mathrm{A}+"$ \\
\hline Self-rated Mathematical Ability & 5 -point scale: $1=$ "Lowest $10 \% "$ to $5=$ "Highest $10 \% "$ \\
\hline Future Activity: Make at least a 'B' average & 4-point scale: $1=$ "No Chance" to $4=$ "Very Good Chance" \\
\hline Future Activity: Change Major Field & 4-point scale: 1 = "No Chance" to $4=$ "Very Good Chance" \\
\hline \multicolumn{2}{|l|}{ Degree Aspirations (vs. Bachelor's or less) } \\
\hline Ph.D & Dichotomous: $0=$ All Others, $1=\mathrm{PhD}$ \\
\hline Law & Dichotomous: $0=$ All Others, $1=$ Law \\
\hline Medical Degree & Dichotomous: $0=$ All Others, $1=$ Medical \\
\hline Master's Degree/M.Div. & Dichotomous: 0 = All Others, 1 = Master's or M.Div. \\
\hline \multicolumn{2}{|l|}{ Personality, Interests and Goals } \\
\hline Leader Personality Factor & See Table A2 \\
\hline Scholar Personality Factor & See Table A2 \\
\hline Goal: Develop a meaningful philosophy of life & 4-point scale: $1=$ "Not Important" to $4=$ "Essential" \\
\hline Goal: Make a theoretical contribution to science & 4-point scale: $1=$ "Not Important" to $4=$ "Essential" \\
\hline Goal: Raise a family & 4-point scale: 1 = "Not Important" to $4=$ "Essential" \\
\hline Social Activist Personality Factor & See Table A2 \\
\hline Artistic Personality Factor & See Table A2 \\
\hline Status Striver Personality Factor & See Table A2 \\
\hline Education Reasons for choosing a College Factor & See Table A2 \\
\hline Extrinsic Reasons for choosing a College Factor & See Table A2 \\
\hline
\end{tabular}

\section{Factor Analysis Procedures}

Exploratory factor analysis using Principal Axis Factoring with Promax rotation was conducted to determine what factors would be used for the regression analysis. Factor analysis was guided by previously constructed factors from Astin's model of student types [73] as well as Sax's [74] typology and college choice factors. Of the 65 independent variables considered, forty-one variables were grouped into seven factors. (See Table A2 for a list of factors, their loadings, and reliability). The threshold for reliability was set at a Cronbach's alpha of 0.65 , and variables were only considered valid for inclusion in a factor if they loaded at .40 or higher (ultimately, all loadings exceeded 0.60 ).

Table A2. Factor Variables, Loadings, and Reliabilities.

\begin{tabular}{lcc}
\hline \multirow{2}{*}{ Factor } & \multicolumn{2}{c}{ Factor Loading } \\
\cline { 2 - 3 } & Men & Women \\
\hline Leader Personality & $\alpha=0.66$ & $\alpha=0.65$ \\
\hline Self Rating: Drive to Achieve & 0.72 & 0.71 \\
Self-Rating: Leadership Ability & 0.83 & 0.83 \\
Self-Rating: Self-confidence (social) & 0.77 & 0.75 \\
\hline Scholar Personality & $\alpha=0.64$ & $\alpha=0.64$ \\
\hline Self-rated: Academic ability & 0.80 & 0.79 \\
Self-rated: Self-confidence (intellectual) & 0.78 & 0.78 \\
Self-rated: Writing ability & 0.72 & 0.73 \\
\hline Social Activist Personality & $\alpha=0.76$ & $\alpha=0.72$ \\
\hline Goal: Influence social values & 0.77 & 0.74 \\
Goal: Participate in a community action program & 0.76 & 0.75 \\
Goal: Help others in difficulty & 0.65 & 0.61 \\
Goal: Influence the political structure & 0.72 & 0.69 \\
Goal: Becoming involved in programs to clean up the environment & 0.67 & 0.64 \\
\hline Artistic Personality & $\alpha=0.72$ & $\alpha=0.69$ \\
\hline Goal: Create artistic work & 0.83 & 0.82 \\
Self-rated: Artistic ability & 0.66 & 0.72 \\
Goal: Write original works & 0.75 & 0.67 \\
Goal: Become accomplished in the performing arts & 0.73 & 0.66 \\
\hline
\end{tabular}


Table A2. Cont.

\begin{tabular}{lcc}
\hline \multirow{2}{*}{ Factor } & \multicolumn{2}{c}{ Factor Loading } \\
\cline { 2 - 3 } & Men & Women \\
\hline Status Striver Personality & $\alpha=0.64$ & $\alpha=0.64$ \\
\hline Goal: Obtain recognition from colleagues & 0.78 & 0.78 \\
Goal: Be very well-off financially & 0.64 & 0.64 \\
Goal: Become authority in my field & 0.75 & 0.74 \\
Goal: Be successful in a business of my own & 0.62 & 0.62 \\
\hline Education Reasons for Choosing College & $\alpha=0.63$ & $\alpha=0.60$ \\
\hline Reason: To gain a general education and appreciation of ideas & 0.79 & 0.76 \\
Reason: To make me a more cultured person & 0.78 & 0.77 \\
Reason: Learn more about things that interest me & 0.73 & 0.73 \\
\hline Extrinsic Reasons for Choosing College & $\alpha=0.67$ & $\alpha=0.66$ \\
\hline Reason: To be able to get a better job & 0.87 & 0.86 \\
Reason: To be able to make more money & 0.87 & 0.86 \\
\hline
\end{tabular}

\section{Data Analysis}

We included two dummy variables for parents' employment in engineering (father engineer $=1$ if the student reports that the father is employed as an engineer, 0 otherwise; and mother engineer $=1$ if the mother is an employed as an engineer, 0 otherwise). The baseline mode includes just these two intergenerational measures. We then added all other variables to assess whether the effect of the parental measures was mediated by other factors.

A set of 30 variables was categorized into four blocks. Variables were added in groups in order. The groups included: (1) race, ethnicity and religion; (2) socio-economic characteristics; (3) learning experiences, self-rated abilities, and educational aspirations; and (4) personality, interests and goals.

The key regression findings are summarized in the results section above. The full regression analyses are presented below as Table A3 (logistic regressions) and Table A4 (OLS regressions). While Mood has raised concerns about the interpretation of logistic regression coefficients, in this particular case the OLS and logistic findings are quite similar. We correlated the OLS and logistic coefficients across the 31 variables in the model. The association is extremely closely for men (Pearson's $r=0.98$ ) and nearly as close for women $(r=0.90)$. The signs and directions of the coefficients are consistent across the OLS and logistic specifications.

There are many interesting coefficients in theses analyses that are not the principal focus of this paper. Selected findings of note include the following. Women who plan to have a family by age 30 are less likely to plan a career in engineering, while the same goal does not deter young men. Self-rated ability in mathematics substantially increases the chances of expressing interest in a career in engineering for both men and women, as does interest in making a contribution to science. Interest in developing a meaningful philosophy of life, and factor scores for status striving, social activism are all negatively related to planning a career in engineering. The leadership factor has a negative sign for men but not statistically significant for women. These results are consistent with those found in previous studies of engineering and STEM majors.

The key finding that we stress in this paper is the effect of father's and mother's employment in engineering. This effect continues to be statistically significant in the final model, even after race, ethnicity, religion and other socio-economic factors are controlled. The parental effect is partially mediated by educational plans and values for men and somewhat more so for women, but the clear majority of the parental effect remains even after all of these variables are taken into account. 
Table A3. Logistic Regression Results: Final Model.

\begin{tabular}{|c|c|c|c|c|c|c|c|c|c|c|c|}
\hline \multicolumn{12}{|c|}{ Logistic Regression } \\
\hline \multicolumn{6}{|c|}{ Male Freshman } & \multicolumn{6}{|c|}{ Female Freshman } \\
\hline \multicolumn{6}{|c|}{ Variables in the Equation } & \multicolumn{6}{|c|}{ Variables in the Equation } \\
\hline & B & S.E. & Wald & Sig. & $\operatorname{Exp}(B)$ & & B & S.E. & Wald & Sig. & $\operatorname{Exp}(B)$ \\
\hline FC_Engineering & 0.798 & 0.014 & 3253.312 & 0.000 & 2.220 & FC_Engineering & 0.750 & 0.024 & 995.666 & 0.000 & 2.116 \\
\hline MC_Engineering & 0.533 & 0.053 & 100.838 & 0.000 & 1.704 & MC_Engineering & 0.715 & 0.068 & 110.360 & 0.000 & 2.043 \\
\hline YEAR & -0.140 & 0.004 & 1314.186 & 0.000 & 0.869 & YEAR & -0.073 & 0.008 & 91.981 & 0.000 & 0.930 \\
\hline Dummy: Asian & 0.123 & 0.020 & 38.582 & 0.000 & 1.131 & Dummy: Asian & 0.370 & 0.033 & 126.825 & 0.000 & 1.448 \\
\hline Dummy: Black & 0.468 & 0.023 & 397.921 & 0.000 & 1.597 & Dummy: Black & 0.954 & 0.037 & 676.325 & 0.000 & 2.595 \\
\hline Dummy: Latino & 0.293 & 0.027 & 120.172 & 0.000 & 1.341 & Dummy: Latino & 0.701 & 0.046 & 234.301 & 0.000 & 2.017 \\
\hline Dummy: Other including American Indian and Multi & 0.118 & 0.021 & 32.486 & 0.000 & 1.125 & Dummy: Other including American Indian and Multi & 0.346 & 0.036 & 93.266 & 0.000 & 1.413 \\
\hline SReligion: Catholic & 0.065 & 0.011 & 33.828 & 0.000 & 1.067 & SReligion: Catholic & 0.208 & 0.022 & 92.528 & 0.000 & 1.231 \\
\hline SReligion: Jewish & -0.655 & 0.031 & 440.840 & 0.000 & 0.519 & SReligion: Jewish & -0.371 & 0.062 & 35.398 & 0.000 & 0.690 \\
\hline SReligion: Other & 0.008 & 0.019 & 0.155 & 0.694 & 1.008 & SReligion: Other & 0.109 & 0.036 & 9.278 & 0.002 & 1.115 \\
\hline SReligion: None & -0.121 & 0.014 & 76.915 & 0.000 & 0.886 & SReligion: None & 0.100 & 0.027 & 14.016 & 0.000 & 1.105 \\
\hline Father's education & -0.028 & 0.003 & 83.533 & 0.000 & 0.973 & Father's education & 0.029 & 0.006 & 25.030 & 0.000 & 1.030 \\
\hline Mother's education & 0.006 & 0.003 & 2.944 & 0.086 & 1.006 & Mother's education & 0.034 & 0.006 & 30.665 & 0.000 & 1.035 \\
\hline Income quintiles & -0.043 & 0.004 & 106.034 & 0.000 & 0.958 & Income quintiles & 0.032 & 0.008 & 15.560 & 0.000 & 1.032 \\
\hline $\begin{array}{l}\text { Do you have any concern about your ability to finance } \\
\text { your college education? }\end{array}$ & 0.040 & 0.008 & 26.592 & 0.000 & 1.040 & $\begin{array}{l}\text { Do you have any concern about your ability to finance } \\
\text { your college education? }\end{array}$ & 0.025 & 0.015 & 2.884 & 0.089 & 1.025 \\
\hline What was your average grade in high school? & 0.167 & 0.004 & 1958.951 & 0.000 & 1.181 & What was your average grade in high school? & 0.272 & 0.009 & 923.098 & 0.000 & 1.313 \\
\hline Self Rating: Mathematical ability & 0.747 & 0.007 & 13025.082 & 0.000 & 2.111 & Self Rating: Mathematical ability & 1.096 & 0.013 & 7512.946 & 0.000 & 2.992 \\
\hline Future Act: Make at least a ' $\mathrm{B}$ ' average & -0.081 & 0.009 & 88.221 & 0.000 & 0.922 & Future Act: Make at least a ' $B$ ' average & -0.239 & 0.017 & 207.048 & 0.000 & 0.787 \\
\hline Degree Asp: Ph.D. & -0.523 & 0.015 & 1154.369 & 0.000 & 0.593 & Degree Asp: Ph.D. & -0.231 & 0.029 & 62.641 & 0.000 & 0.794 \\
\hline Degree Asp: Med. & -3.136 & 0.037 & 7165.405 & 0.000 & 0.043 & Degree Asp: Med. & -2.416 & 0.053 & 2079.808 & 0.000 & 0.089 \\
\hline Degree Asp: Masters non Med. & -0.002 & 0.011 & 0.022 & 0.883 & 0.998 & Degree Asp: Masters non Med. & 0.204 & 0.023 & 75.724 & 0.000 & 1.226 \\
\hline Leader: REGR factor score & -0.048 & 0.006 & 73.898 & 0.000 & 0.953 & Leader: REGR factor score & 0.007 & 0.011 & 0.407 & 0.523 & 1.007 \\
\hline Goal: Developing a meaningful philosophy of life & -0.053 & 0.006 & 91.881 & 0.000 & 0.948 & Goal: Developing a meaningful philosophy of life & -0.038 & 0.011 & 13.172 & 0.000 & 0.962 \\
\hline Goal: Making a theoretical contribution to science & 0.780 & 0.006 & 17383.451 & 0.000 & 2.182 & Goal: Making a theoretical contribution to science & 0.830 & 0.010 & 6592.794 & 0.000 & 2.293 \\
\hline Goal: Raising a family & 0.054 & 0.005 & 96.431 & 0.000 & 1.055 & Goal: Raising a family & -0.121 & 0.010 & 159.509 & 0.000 & 0.886 \\
\hline Scholar: REGR factor score & -0.216 & 0.007 & 1084.228 & 0.000 & 0.806 & Scholar: REGR factor score & -0.098 & 0.013 & 60.751 & 0.000 & 0.907 \\
\hline Social Activism: REGR factor score & -0.320 & 0.006 & 2524.803 & 0.000 & 0.726 & Social Activism: REGR factor score & -0.256 & 0.012 & 455.184 & 0.000 & 0.774 \\
\hline Artistic: REGR factor score & -0.182 & 0.006 & 919.841 & 0.000 & 0.834 & Artistic: REGR factor score & -0.190 & 0.011 & 290.775 & 0.000 & 0.827 \\
\hline Status Striver: REGR factor score & -0.153 & 0.006 & 699.422 & 0.000 & 0.858 & Status Striver: REGR factor score & -0.123 & 0.011 & 125.711 & 0.000 & 0.884 \\
\hline Ed Reasons:REGR factor score & -0.057 & 0.005 & 137.500 & 0.000 & 0.944 & Ed Reasons:REGR factor score & -0.107 & 0.010 & 106.263 & 0.000 & 0.898 \\
\hline Ex Reasons: REGR factor score & 0.305 & 0.006 & 2646.099 & 0.000 & 1.356 & Ex Reasons: REGR factor score & 0.253 & 0.011 & 532.042 & 0.000 & 1.288 \\
\hline Constant & -6.311 & 0.050 & 15776.190 & 0.000 & 0.002 & Constant & -10.245 & 0.107 & 9090.693 & 0.000 & 0.000 \\
\hline
\end{tabular}


Table A4. OLS Regression Results, Final Model.

\begin{tabular}{|c|c|c|c|c|c|c|c|c|c|c|c|}
\hline \multicolumn{6}{|c|}{ Male Freshmen } & \multicolumn{6}{|c|}{ Female Freshmen } \\
\hline & oefficien & & & & & & Coefficients ${ }^{a}$ & & & & \\
\hline \multirow{2}{*}{ Model } & \multicolumn{2}{|c|}{$\begin{array}{l}\text { Unstandardized } \\
\text { Coefficients }\end{array}$} & \multirow{2}{*}{$\begin{array}{c}\begin{array}{c}\text { Standardized } \\
\text { Coefficients }\end{array} \\
\text { Beta }\end{array}$} & \multirow[t]{2}{*}{$\mathrm{t}$} & \multirow{2}{*}{ Sig. } & \multirow{2}{*}{ Model } & \multirow{2}{*}{$\begin{array}{c}\begin{array}{c}\text { Unstandardized } \\
\text { Coefficients }\end{array} \\
\text { B }\end{array}$} & \multirow{2}{*}{$\begin{array}{c}\begin{array}{c}\text { Standardized } \\
\text { Coefficients }\end{array} \\
\text { Std. Error }\end{array}$} & \multirow{2}{*}{$\frac{\mathrm{t}}{\mathrm{B}}$} & \multirow[t]{2}{*}{ Sig. } & \multirow[t]{2}{*}{ Sig } \\
\hline & B & Std. Error & & & & & & & & & \\
\hline (Constant) & -0.274 & 0.005 & & -54.463 & 0.000 & (Constant) & -0.106 & 0.002 & & -43.884 & 0.000 \\
\hline FC_Engineering & 0.11 & 0.002 & 0.087 & 61.839 & 0.000 & FC_Engineering & 0.032 & 0.001 & 0.053 & 38.261 & 0.000 \\
\hline MC_Engineering & 0.081 & 0.007 & 0.016 & 11.485 & 0.000 & MC_Engineering & 0.061 & 0.003 & 0.027 & 19.328 & 0.000 \\
\hline YEAR & -0.015 & 0 & -0.06 & -37.385 & 0.000 & YEAR & -0.002 & 0.000 & -0.014 & -9.024 & 0.000 \\
\hline Dummy: Asian & 0.007 & 0.002 & 0.005 & 3.262 & 0.001 & Dummy: Asian & 0.013 & 0.001 & 0.018 & 12.309 & 0.000 \\
\hline Dummy: Black & 0.041 & 0.003 & 0.024 & 16.587 & 0.000 & Dummy: Black & 0.021 & 0.001 & 0.03 & 20.41 & 0.000 \\
\hline Dummy: Latino & 0.029 & 0.003 & 0.014 & 9.832 & 0.000 & Dummy: Latino & 0.017 & 0.001 & 0.019 & 13.246 & 0.000 \\
\hline $\begin{array}{l}\text { Dummy: Other including American Indian } \\
\text { and Multi }\end{array}$ & 0.012 & 0.002 & 0.008 & 5.525 & 0.000 & $\begin{array}{l}\text { Dummy: Other including American Indian } \\
\text { and Multi }\end{array}$ & 0.009 & 0.001 & 0.013 & 9.293 & 0.000 \\
\hline Religion: Catholic & 0.007 & 0.001 & 0.009 & 6.004 & 0.000 & Religion: Catholic & 0.005 & 0.001 & 0.012 & 8.148 & 0.000 \\
\hline Religion: Jewish & -0.05 & 0.003 & -0.028 & -19.144 & 0.000 & Religion: Jewish & -0.006 & 0.001 & -0.007 & -4.85 & 0.000 \\
\hline Religion: Other & 0.002 & 0.002 & 0.001 & 0.946 & 0.344 & Religion: Other & 0.003 & 0.001 & 0.005 & 3.484 & 0.000 \\
\hline Religion: None & -0.008 & 0.001 & -0.008 & -5.121 & 0.000 & Religion: None & 0.005 & 0.001 & 0.01 & 6.727 & 0.000 \\
\hline Father's education & -0.003 & 0.000 & -0.016 & -8.553 & 0.000 & Father's education & 0.001 & 0.000 & 0.012 & 6.465 & 0.000 \\
\hline Mother's education & 0.001 & 0.000 & 0.004 & 2.058 & 0.040 & Mother's education & 0.001 & 0.000 & 0.011 & 5.982 & 0.000 \\
\hline Income quintiles & -0.004 & 0.000 & -0.016 & -9.791 & 0.000 & Income quintiles & 0.001 & 0.000 & 0.006 & 3.741 & 0.000 \\
\hline $\begin{array}{l}\text { Do you have any concern about your ability to } \\
\text { finance your college education? }\end{array}$ & 0.005 & 0.001 & 0.009 & 6.104 & 0.000 & $\begin{array}{l}\text { Do you have any concern about your ability to } \\
\text { finance your college education? }\end{array}$ & 0.001 & 0.000 & 0.003 & 2.291 & 0.022 \\
\hline What was your average grade in high school? & 0.018 & 0.000 & 0.082 & 46.971 & 0.000 & What was your average grade in high school? & 0.005 & 0.000 & 0.045 & 26.984 & 0.000 \\
\hline Self-Rating: Mathematical ability & 0.067 & 0.001 & 0.185 & 112.229 & 0.000 & Self-Rating: Mathematical ability & 0.023 & 0.000 & 0.137 & 88.259 & 0.000 \\
\hline Future Act: Make at least a ' $\mathrm{B}$ ' average & -0.005 & 0.001 & -0.009 & -5.641 & 0.000 & Future Act: Make at least a ' $\mathrm{B}$ ' average & -0.006 & 0.000 & -0.021 & -13.802 & 0.000 \\
\hline Degree Asp: PhD & -0.048 & 0.002 & -0.05 & -28.704 & 0.000 & Degree Asp: PhD & -0.002 & 0.001 & -0.005 & -3.227 & 0.001 \\
\hline Degree Asp: Med & -0.227 & 0.002 & -0.191 & -114.528 & 0.000 & Degree Asp: Med & -0.058 & 0.001 & -0.108 & -64.568 & 0.000 \\
\hline Degree Asp: Masters non Med & 0.004 & 0.001 & 0.005 & 2.785 & 0.005 & Degree Asp: Masters non Med & 0.006 & 0.001 & 0.017 & 9.95 & 0.000 \\
\hline Leader: REGR factor score & -0.007 & 0.001 & -0.021 & -12.347 & 0.000 & Leader: REGR factor score & 0.000 & 0.000 & 0.001 & 0.586 & 0.558 \\
\hline Goal: Developing a meaningful philosophy of life & -0.005 & 0.001 & -0.014 & -8.374 & 0.000 & Goal: Developing a meaningful philosophy of life & -0.001 & 0.000 & -0.005 & -2.803 & 0.005 \\
\hline Goal: Making a theoretical contribution to science & 0.091 & 0.001 & 0.227 & 141.784 & 0.000 & Goal: Making a theoretical contribution to science & 0.029 & 0.000 & 0.146 & 94.044 & 0.000 \\
\hline Goal: Raising a family & 0.005 & 0.001 & 0.012 & 8.029 & 0.000 & Goal: Raising a family & -0.003 & 0.000 & -0.02 & -13.623 & 0.000 \\
\hline Scholar: REGR factor score & -0.016 & 0.001 & -0.043 & -22.606 & 0.000 & Scholar: REGR factor score & 0.001 & 0.000 & 0.004 & 2.205 & 0.027 \\
\hline Social Activism: REGR factor score & -0.035 & 0.001 & -0.098 & -54.135 & 0.000 & Social Activism: REGR factor score & -0.008 & 0.000 & -0.047 & -27.214 & 0.000 \\
\hline Artistic: REGR factor score & -0.017 & 0.001 & -0.047 & -30.235 & 0.000 & Artistic: REGR factor score & -0.005 & 0.000 & -0.028 & -18.442 & 0.000 \\
\hline Status Striver: REGR factor score & -0.015 & 0.001 & -0.04 & -24.457 & 0.000 & Status Striver: REGR factor score & -0.002 & 0.000 & -0.015 & -9.177 & 0.000 \\
\hline Ed Reasons: REGR factor score & -0.006 & 0.001 & -0.017 & -11.117 & 0.000 & Ed Reasons: REGR factor score & -0.003 & 0.000 & -0.015 & -9.999 & 0.000 \\
\hline Ex Reasons: REGR factor score & 0.026 & 0.001 & 0.072 & 47.36 & 0.000 & Ex Reasons: REGR factor score & 0.005 & 0 & 0.03 & 20.193 & 0.000 \\
\hline
\end{tabular}




\section{References}

1. Cinda-Sue Davis, Angela B. Ginorio, Carol S. Hollenshead, Barbara B. Lazarus, and Paula M. Rayman. The Equity Equation: Fostering the Advancement of Women in the Sciences, Mathematics, and Engineering. San Francisco: Jossey-Bass, 1996.

2. Gerald Holton, and Gerhard Sonnert. Who Succeeds in Science? The Gender Dimension. New Brunswick: Rutgers University Press, 1995.

3. Mary Allison Kanny, Linda J. Sax, and Tiffani A. Riggers-Piehl. "Investigating Forty Years of STEM Research: How Explanations for the Gender Gap Have Evolved Over Time." Journal of Women and Minorities in Science and Engineering 20 (2014): 127-48. [CrossRef]

4. Sue V. Rosser. Breaking into the Lab: Engineering Progress for Women in Science. New York: New York University Press, 2012.

5. Society of Women Engineers. A Compendium of SWE Annual Literature Reviews on Women in Engineering through. Chicago: Society of Women Engineers, 2011. Available online: http://www.aacei.org/wpc/library/ SWE_LitReview2011.pdf (accessed on 27 December 2016).

6. Jill Bystydzienski, and Sharon R. Bird, eds. Removing Barriers: Women in Academic Science, Technology, Engineering, and Mathematics. Bloomingdale: Indiana University Press, 2006.

7. National Academy of Sciences. Biological, Social and Organizational Components of Success for Women in Academic Science and Engineering. Washington: National Academies Press, 2006.

8. National Academy of Sciences. Beyond Bias and Barriers: Fulfilling the Potential of Women in Academic Science and Engineering. Washington: National Academies Press, 2007.

9. Margaret W. Rossiter. Women Scientists in America: Forging a New World since 1972. Baltimore: Johns Hopkins University Press, 2012.

10. Susan S. Case, and Bonnie Ann Richley. "Gendered Institutional Research Cultures in Science: The Post-Doc Transition for Women Scientists." Community, Work \& Family 16 (2013): 327-49. [CrossRef]

11. Yu Xie, and Kimberlee A. Shauman. Women in Science: Career Processes and Outcomes. Cambridge: Harvard University Press, 2003.

12. US Department of Labor Bureau of Labor Statistics. “May 2015 National Industry-Specific Occupational Employment and Wage Estimates." Available online: https://www.bls.gov/oes/current/oessrci.htm (accessed on 27 December 2016).

13. Stephen Olson, ed. The Importance of Engineering Talent to the Prosperity and Security of the Nation: Summary of a Forum. Washington: National Academy Press, 2014.

14. Peter Meiksins, and Chris Smith. "Organizing Engineering Work: A Comparative Analysis." Work E Occupations 20 (1993): 123-56. [CrossRef]

15. Andrew Abbott. The System of Professions. Chicago: University of Chicago Press, 1988.

16. Daniel Bell. The Coming of the Post-Industrial Society. New York: Basic Books, 1976.

17. Judith S. Mcllwee, and J. Gregg Robinson. Women in Engineering: Gender, Power, and Workplace Culture. Albany: SUNY (State University of New York) Press, 1992.

18. Carroll Seron, Susan S. Silbey, Erin Cech, and Brian Rubineau. "Persistence Is Cultural: Professional Socialization and the Reproduction of Sex Segregation." Work and Occupations 43 (2016): 178-214. [CrossRef]

19. Kevin Eagan, Ellen Bara Stolzenberg, Joseph J. Ramirez, Melissa C. Aragon, Maria Ramirez Suchard, and Cecilia Rios-Aguilar. The American Freshman: Fifty-Year Trends, 1966-2015. Los Angeles: Higher Education Research Institute, UCLA, 2016.

20. U.S. Department of Education (USDOE), and National Center for Education Statistics. "Digest of Education Statistics." Available online: http://nces.ed.gov/programs/digest/2011menu_tables.asp (accessed on 27 December 2016).

21. Joanna Sikora, and Artur Pokropek. "Intergenerational Transfers of Preferences for Science Careers in Comparative Perspective." International Journal of Science Education 34 (2012): 2501-27. [CrossRef]

22. Alexander W. Astin, and Helen S. Astin. Undergraduate Science Education: The Impact of Differential College Environments on the Educational Pipeline in the Sciences. Los Angeles: Higher Education Research Institute, UCLA, 1992.

23. Erin Cech, Brian Rubineau, Susan Silbey, and Caroll Seron. "Professional role confidence and gendered persistence in engineering." American Sociological Review 76 (2011): 641-66. [CrossRef] 
24. Anne E. Preston. Leaving Science: Occupational Exit from Scientific Careers. New York: Russell Sage, 2004.

25. Elaine Seymour. Talking about Leaving: Why Undergraduates Leave the Sciences. Boulder: Westview Press, 2000.

26. Mary Frank Fox, Gerhard Sonnert, and Irina Nikforova. "Programs for Undergraduate Women in Science and Engineering Issues, Problems, and Solutions." Gender E Society 25 (2011): 589-615. [CrossRef]

27. Catherine Good, Joshua Aronson, and Jayne Ann Harder. "Problems in the pipeline: Stereotype threat and women's achievement in high-level math courses." Journal of Applied Developmental Psychology 29 (2007): 17-28. [CrossRef]

28. Catherine Riegle-Crumb, Barbara King, Eric Grodsky, and Chandra Muller. "The More Things Change, the More They Stay the Same? Prior Achievement Fails to Explain Gender Inequality in Entry Into STEM College Majors Over Time." American Educational Research Journal 49 (2012): 1048-73. [CrossRef] [PubMed]

29. Bryce E. Hughes, Juan C. Garibay, Sylvia Hurtado, and Kevin Eagan. "Examining the Tracks That Cause Derailment: Institutional Contexts and Engineering Degree Attainments." Paper presented at the American Educational Research Association Annual Forum, San Francisco, CA, USA, 27 April-1 May 2013.

30. Michelle Verquer, Terry A. Beehr, and Stephen H. Wagner. "A meta-analysis of relations between person-organization fit and work attitudes." Journal of Vocational Behavior 63 (2003): 473-89. [CrossRef]

31. John L. Holland. Making Vocational Choices: A Theory of Vocational Personalities and Work Environments, 3rd ed. Odessa: Psychological Assessment Resources, 1997.

32. Emily Beller, and Michael Hout. "Intergenerational social mobility: The United States in Comparative Perspective." Future of Children 16 (2006): 19-36. Available online: http:/ / muse.jhu.edu/journals/future_of_ children/v016/16.2beller.pdf (accessed on 27 December 2016). [CrossRef] [PubMed]

33. Robert M. Hauser, and John Robert Warren. A Socioeconomic Index for Occupations: A Review, Update and Critique. Madison: Center for Demography and Ecology, University of Wisconsin, 1996.

34. Gary Solon. "Intergenerational income mobility in the United States." American Economic Review 82 (1992): 393-408. Available online: http://www.jstor.org/stable/2117312 (accessed on 27 December 2016).

35. Gary Solon. "Theoretical models of inequality transmission across generations." Research in Social Stratification and Mobility 35 (2014): 13-18. [CrossRef]

36. Heather Janiszewski Goodin. "The nursing shortage in the United States of America: An integrative review of the literature." Journal of Advanced Nursing 43 (2003): 335-43. [CrossRef]

37. Richard J. Ingersoll. "Teacher Turnover and Teacher Shortages: An Organizational Analysis." American Educational Research Journal 38 (2001): 499-534. [CrossRef]

38. Michael E. White, Jonathon A. Cooper, Jessica Saunders, and Anthony J. Raganella. "Motivations for becoming a police officer: Re-assessing officer attitudes and job satisfaction after six years on the street." Journal of Criminal Justice 38 (2010): 520-30. [CrossRef]

39. John H. Faris. “The All-Volunteer Force: Recruitment from Military Families." Armed Forces E Society 7 (1981): 545-59. Available online: http://afs.sagepub.com/content/7/4/545.full.pdf+html (accessed on 27 December 2016). [CrossRef]

40. Howard E. Aldrich, and Phillip H. Kim. "A Life Course Perspective on Occupational Inheritance: Self-employed Parents and their Children." In The Sociology of Entrepreneurship (Research in the Sociology of Organizations, Volume 25). Edited by Martin Ruef and Michael Lounsbury. Bingley: Emerald Group Publishing Limited, 2004, pp. 33-82.

41. Jesper B. Sorensen. "Closure and Exposure: Mechanisms in the Intergenerational Transmission of Self-employment." Research in the Sociology of Organizations 25 (2004): 83-124. Available online: http://www.emeraldinsight.com/journals.htm?articleid=1758695\&show=abstract (accessed on 27 December 2016).

42. University of Minnesota. “Voices of Experience: Parent Advice about Career Choices." Available online: http:/ / www1.umn.edu/parent/advice-involvement/voices-of-experience/career-choices/ (accessed on 14 January 2014).

43. AT\&T Parent Project. "Parent Guide to Careers: 10 Steps to Help Your Child Prepare for a Career." Available online: http://www.takestockinchildren.org/pdf/resources-parents-careerplanning.pdf (accessed on 18 February 2015).

44. Maria Charles, Corrie Ellis, and Paula England. "Is There a Caring Class? Intergenerational Transmission of Care Work." Sociological Science 2 (2015): 527-43. [CrossRef] 
45. Viktor Gecas, and Monica A. Seff. "Families and adolescents: a review of the 1980s." Journal of Marriage and the Family 52 (1990): 941-58. [CrossRef]

46. Steven Hitlin, and Jane Allyn Piliavin. "Values: Reviving a dormant concept." Annual Review of Sociology 30 (2004): 359-93. [CrossRef]

47. Monica K. Johnson, and Jeylan T. Mortimer. "Career choice and development from a sociological perspective." In Career Choice and Development, 4th ed. Edited by Duane Brown. San Francisco: Jossey-Bass, 2002, pp. 37-84.

48. David N. Laband, and Bernard F. Lentz. Roots of Success: Why Children Follow in Their Parent's Career Footsteps. New York: Praeger, 1985.

49. Tom W. Smith. Job Satisfaction in the United States. Chicago: National Opinion Research Center, University of Chicago, 2007.

50. Gallup Poll. "Medical Careers Seen as Best Choice for Young Men, Women." Available online: http:/ / www.gallup.com/poll/122087/Medical-Careers-Seen-Best-Choice-Young-Men-Women.aspx\#1 (accessed on 27 December 2016).

51. Engineering.com. "2010 Job Prospects for Engineers." Available online: www.engineering. com/Library /ArticlesPage/tabid/85/ArticleID/824/2010-Job-Prospects-for-Engineers.aspx (accessed on 27 December 2016).

52. Arne Kalleberg, and Karen Loscocco. “Aging, values and rewards: Explaining age differences in job satisfaction." American Sociological Review 49 (1983): 78-90. [CrossRef]

53. Lisa Frehill. "Satisfaction." Mechanical Engineering 132 (2010): 38-41.

54. Jane Lewis. "The decline of the male breadwinner model: Implications for work and care." Social Politics 8 (2001): 152-69. [CrossRef]

55. Jan O. Jonsson, David B. Grusky, Matthew Di Carlo, Reinhard Pollak, and Mary C. Brinton. "Micro-class mobility: Social reproduction in four countries." American Journal of Sociology 114 (2009): 977-1036. [CrossRef]

56. Matthus Kalmijn. "Mother's Occupational Status and Children's schooling." American Sociological Review 59 (1994): 257-75. [CrossRef]

57. Geoff Payne, and Pamela Abbott, eds. The Social Mobility of Women: Beyond Male Mobility Models. London: The Falmer Press/Taylor and Francis, 2005.

58. Diane Lavery. "More Mothers of Young Children in U.S. Workforce." Available online: http://www.prb. org/Publications / Articles/2012/us-working-mothers-with-children.aspx (accessed on 27 December 2016).

59. Elizabeth M. Almquist, and Shirley S. Angrist. “Role model influences on college women's career aspirations." Merrill Palmer Quarterly 17 (1971): 263-79.

60. Kathleen Gerson. Hard Choices: How Women Decide About Work, Career and Motherhood. Berkeley: University of California Press, 1986.

61. Nilanjana Dasgupta, and Shaki Asgari. "Seeing is believing: Exposure to counter-stereotypic women leaders and its effect on the malleability of automatic gender stereotyping." Journal of Experimental Social Psychology 40 (2004): 642-58. [CrossRef]

62. Gary Marks. "Gender differences in the effects of socioeconomic background." International Sociology 23 (2008): 845-63. [CrossRef]

63. Christine Schwartz, and Robert D. Mare. "Trends in Educational Assortative Marriage from 1940-2003." Demography 42 (2005): 621-46. [CrossRef] [PubMed]

64. Judith K. Hellerstein, and Melinda Sandler Morrill. "Dads and Daughters: The Changing Impact of Fathers on Women's Occupational Choices." Journal of Human Resources 46 (2011): 333-72. [CrossRef]

65. Carina Mood. "Logistic Regression: Why We Cannot Do What We Think We Can Do, and What We Can Do About It." European Sociological Review 26 (2010): 67-82. [CrossRef]

66. Robert W. Lent, Steven D. Brown, and Gail Hackett. "Toward a unifying social cognitive theory of career and academic interest, choice, and performance." Journal of Vocational Behavior 45 (1994): 79-122. [CrossRef]

67. Jody L. Fitzpatrick, and Traci Silverman. "Women's Selection of Careers in Engineering: Do Traditional-Nontraditional Differences Still Exist? " Journal of Vocational Behavior 34 (1989): 266-78. [CrossRef]

68. Jerry A. Jacobs, and Linda J. Sax. "STEM Majors and the Great Recession." Unpublished manuscript, Department of Sociology, University of Pennsylvania, 2015.

69. Ann Boulis, and Jerry A. Jacobs. The Changing Face of Medicine: Women Doctors and the Evolution of Health Care in America. Ithaca: Cornell University Press; New York: Cornell University Press, 2006. 
70. Linda J. Sax. "Undergraduate science majors: Gender differences in who goes to graduate school." Review of Higher Education 24 (2001): 153-72. [CrossRef]

71. Alaya Malach-Pines, and Mustafa F. Ozbilgin, eds. Handbook of Research on High-Technology Entrepreneurs. Cheltenham: Edward Elgasar, 2010.

72. Julie P. Martin, Denise R. Simmons, and Shirley L. Yu. “The Role of Social Capital in the Experiences of Hispanic Women Engineering Majors." Journal of Engineering Education 102 (2013): 227-43. [CrossRef]

73. Alexander W. Astin. What Matters in College? Four Critical Years Revisited. San Francisco: Jossey-Bass, 1993, p. 482.

74. Linda J. Sax. The Gender Gap in College: Maximizing the Developmental Potential of Women and Men. San Francisco: Jossey-Bass, 2008.

(C) 2017 by the authors; licensee MDPI, Basel, Switzerland. This article is an open access article distributed under the terms and conditions of the Creative Commons Attribution (CC-BY) license (http://creativecommons.org/licenses/by/4.0/). 